e-ISSN 2392-3458

\title{
THE PRODUCTION AND ECONOMIC RESULTS OF DAIRY FARMS BELONGING TO THE EUROPEAN DAIRY FARMERS IN 2016
}

\author{
EWA KOLOSZYCZ \\ MICHAE ŚWITŁYK
}

\begin{abstract}
The objectives of the work were to check the possibility of obtaining data from the FADN system for the EDF survey and to compare the economic results achieved by dairy farms from the selected EU countries in 2016. The additional objective was to determine the profitability threshold for milk production at the level of general and full costs. The average data was used for the analysis within EDF and the Polish group and their tercyl separated due to the total cost of milk production. The average national results within EDF in 2016 were also analyzed. Measures for the evaluation of the results was the level of agricultural income, and income from management and risks in the dairy industry. Two break even points of producing $100 \mathrm{~kg}$ of milk expressed by total and full costs were also assessed. The lowest total cost of production was incurred by the farm with large scale production, expressed as the number of cows in the herd and milk yield per cow. In addition, these farms were characterised by greater participation of grassland than arable land in forage area, of which more than half was rented. Polish and Irish farms were characterised by the lowest total costs in milk production out of the analyzed countries. Based on the results relying on opportunity costs of own factors in milk production, it should be noted that the Polish farm obtained the lowest entrepreneur income. Apart from Irish farms, milk production in the analyzed countries in 2016 was unprofitable.
\end{abstract}

Keywords: profitability, dairy farm, cost of milk production, dairy farm income.

JEL codes: D24, D33, Q11, Q12.

Dr Ewa Kołoszycz, Zachodniopomorski Uniwersytet Technologiczny w Szczecinie, Wydział Ekonomiczny; ul. Żołnierska 47, 72-210 Szczecin (ewa.koloszycz@zut.edu.pl). ORCID iD: 0000-0001-8508-0772.

Prof. Michał Świttyk, Zachodniopomorski Uniwersytet Technologiczny w Szczecinie, Wydział Ekonomiczny; ul. Żołnierska 47, 72-210 Szczecin (michal.switlyk@zut.edu.pl). ORCID iD: 0000-0002-9494-2802. 


\section{Introduction}

Considerable importance of milk production in the Polish agriculture is confirmed by high value of production and its share in global commodity agricultural production. In 2017, Poland was the fourth producer of cow milk in the EU and the thirteenth in the world (Hemme (ed.), 2018).

In 2016, compared to 2010, the number of farms keeping cows decreased by about $40 \%$ and the cow population decreased by $11 \%$. Statistics show that the number of farms with the economic size up to EUR 8 thousand decreased, and the decline in population concerned in particular farms with the economic size up to EUR 50 thousand (GUS, 2012, 2017).

Significant disproportions in production parameters between the Polish farms and agricultural holdings from Western Europe are still visible. The major ones include differences in the scale of production, resulting from the size of the herd of cows and milk productivity (Czyżewski and Guth, 2016; Ziętara and Adamski, 2018), the efficiency of using resources on farms (Gołaś, 2017; Skarżyńska, 2017).

These parameters affect the profitability of milk production which additionally depends on many external factors, including demand and supply and agricultural policy on the local and global market.

Organisation which monitors the development of the profitability of milk production on farms is the European Dairy Farmers (EDF). The organisation was founded in 1990 in Great Britain. An initiative to create it was undertaken by a few dozen farmers producing milk and the German Agricultural Society (Deutsche Landwirtschafts-Gesellschaft - DLG e. V.) and the Federal Research Institute for Rural Areas, Forestry and Fisheries of the Thünen Institute (then the FAL - Bundesforschungsanstalt für Landwirtschaft). The mission of the EDF is to inspire farmers through the exchange of knowledge and ideas. Activities of the organisation focus on the analysis of milk production costs and the search for the reasons of differences in production and economic results between farms. The advantage of analyses made by the EDF is a uniform method of data collection and determination of results. The organisation brings together milk producers on a voluntary basis and finances its activity entirely from membership fees. The condition for receiving the results of analyses of milk production costs is to provide economic and production data from the farm.

Data from the Polish dairy farms has been analysed in the EDF since 1998. The basic problem for the majority of the Polish farms was keeping too simplified records of economic events. As a result, completion of the survey concerning the summary of the reporting period took a lot of time, and the values in the survey were approximate. Reliable results have a high informative value for the milk producer, they serve not only to assess the completed reporting periods, but also to improve the management of the farm in the future by comparing it with better farms. 


\section{Purpose of the study, data sources and methodology}

The objectives of the paper were to check the possibility of obtaining data from the FADN system for the EDF survey and to compare the economic results achieved by dairy farms from the selected EU countries in 2016 using the methodology of the EDF. An additional goal was to determine the profitability threshold for milk production at the level of general and full costs.

The research covered a group of 362 farms from the EDF and 30 farms from Poland conducting agricultural accounting in the Polish FADN. Data was collected with the participation of the Institute of Agricultural and Food Economics - National Research Institute in Warsaw ${ }^{1}$, in accordance with the FADN methodology and schedule, and then supplemented with information required for cost analysis in the EDF through a structured interview. The interview was carried out by advisers from farm advisory centres operating under the FADN. The selection of farms for analysis was purposeful; 30 farms selected for the study were farms where the share of the milk production value exceeded $70 \%$ of the total sales value were. They can be classified as farms highly specialized in milk production (Bocian, Osuch and Smolik, 2018).

In the analysis of the results, the EDF uses full costing of milk production. Figure 1 presents groups of costs and their components used in the EDF. The EDF calculations assumed that total labour-related costs include both labour costs of people and the costs of machinery. Total costs of labour, buildings, land and milk quota also include alternative costs of own resources.

Full costing required assumptions regarding the valuation of own production factors involved in milk production (land, capital and labour). The calculation of full costs is of particular importance for entities which differ in the ownership structure of the resources used for production. Approaches to the valuation of own resources involved are different in literature on the subject (Goraj and Mańko, 2004; Hemme (ed.), 2018; Skarżyńska, 2011).

\footnotetext{
${ }^{1}$ Data was collected in cooperation with Prof. dr hab. Wojciech Ziętara and mgr inż. Marcin Adamski.
} 


\section{Direct costs}

- Animal production: purchase of animals; services of rearing heifers; costs of insemination, veterinary services and medicines; purchase of feed, other direct costs of livestock production

- Production of own feed: seeds; fertilisation and protection of plants; other direct costs of feed production

Total labour costs

- Remuneration for hired workers, alternative costs of family labour, external services, lease of machinery, fuel, electricity, machinery maintenance, depreciation of machinery, alternative costs of machinery

Total costs of buildings

- Leasing, maintenance, depreciation of buildings, alternative costs of buildings

Total costs of land

- Lease of land, drainage, repair of roads and fences, agricultural tax, alternative costs of own land

Total cost of milk quota

- Leasing and depreciation of milk quota (category existing, e.g. in Canada which participates in cost comparisons)

\section{Other costs}

- Advisory services, insurance, other fees and liabilities, other general economic costs

Fig. 1. Categories of costs in the calculation of milk production costs in the EDF.

Source: own study based on the EDF (2015).

In this analysis, the costs of the so-called lost benefits were determined using the same method in individual countries participating in the study. Alternative costs of own land used in milk production were determined based on the amount of rent in the region of the farm's operation. Valuation of the use of capital in raising of dairy cattle in the EDF surveys was made on the basis of interest rates on loans for nonfinancial enterprises granted for a period of over 5 years. Alternative costs of the family labour were estimated on the basis of the product of the annual workload of family members and remuneration rates (hourly rates were calculated on the basis of gross annual earnings in the national economy without bonuses and rewards). A summary of the basic assumptions regarding the valuation of the involvement of own resources in selected countries for analysis is provided in Figure 2. 


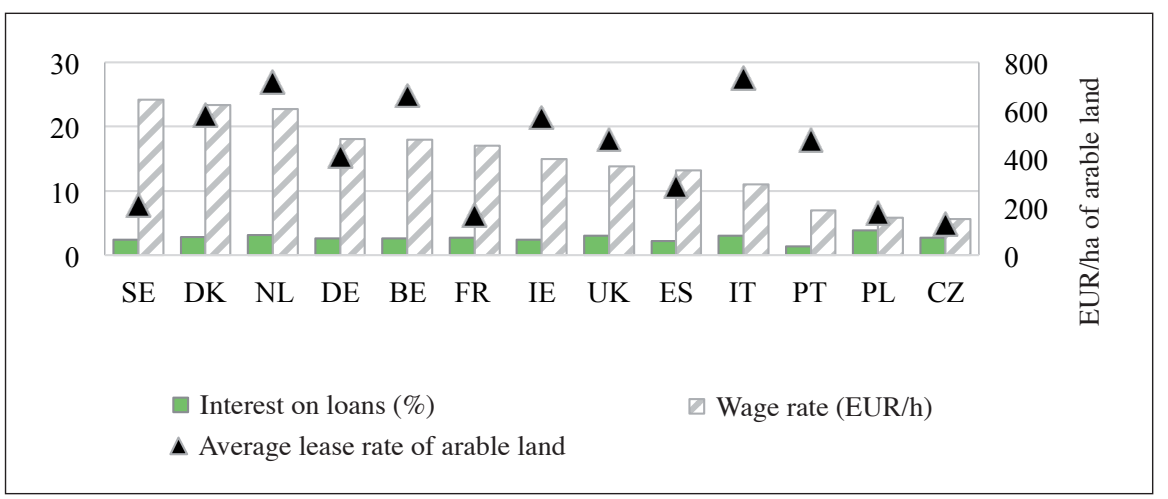

Symbols of countries: CH - Switzerland; SE - Sweden; DK - Denmark; NL -Netherlands; DE - Germany; BE - Belgium; FR - France; IE - Ireland; UK - United Kingdom; ES - Spain; IT - Italy; PT - Portugal; PL - Poland; CZ - Czech Republic.

Fig. 2. Valuation of capital, family labour and the average amount of rent for arable land in selected European countries in the cost analysis of the EDF in 2016.

Source: own study based on data of the EDF.

The adopted assumptions translated directly into the costs of production factors incurred on farms. In Sweden, Denmark and the Netherlands, labour costs in 2016 were among the highest (around EUR 24/h) and were about 4 times higher than average rates in Portugal, Poland and the Czech Republic. The valuation of alternative costs of own forage area was made individually for each farm and was based on the amount of rent of arable land and grassland in the area of the farm's operation. The average amount of rent of arable land for groups of farms from individual countries presented in Figure 2 was characterised by high diversification (higher than in the case of labour prices). The rent of 1 ha of arable land in the Netherlands was around EUR 720, while in the Czech Republic it was over five times lower (EUR 130). Similarly, in the case of capital, there were large differences in interest rates on loans in individual countries.

Basic measures used to assess economic results and the manner of their calculation are given in Table 1. In this analysis, the results were calculated only for raising of dairy cattle. The level of involvement of resources in this production and the share of indirect costs were determined with farmers at the stage of data collection on farms, based on the share of milk production value in the value of total production. The assessment of economic results in milk production in the EDF featured calculation of the so-called break-even point (BEP). It informs about the amount of revenues from the sale of milk, which are required to cover the costs of its production. The EDF methodology assumes that revenues obtained from milk production, but other than the sale of milk (e.g. the sale of cattle), are 'non-core' activity and the farmer obtains them at the level of production costs incurred. These revenues are deducted from the costs of raising of dairy cattle. This way of calculating the cost of milk production is also used in the International Farm Comparison Network (IFCN) - organisation which compares the costs of milk production in the world (Hemme (ed.), 2018). 
Measures used in the analysis of profitability of raising dairy cattle on farms

\begin{tabular}{|c|c|}
\hline Detailed list & Calculation method \\
\hline Total revenues & $\begin{array}{l}\text { The value of the sale of milk and animals (including change in the value } \\
\text { of livestock) and other revenues related to milk production. Revenues } \\
\text { include subsidies related to milk production and VAT balance. }\end{array}$ \\
\hline Full economic costs & $\begin{array}{l}\text { Total costs (the sum of direct costs of animal and plant production, } \\
\text { depreciation, general economic costs and external factors) increased } \\
\text { by the costs of lost opportunities of involved own land, family labour } \\
\text { and equity (without land). }\end{array}$ \\
\hline $\begin{array}{l}\text { Income from an } \\
\text { agricultural holding }\end{array}$ & Total revenues reduced by total costs. \\
\hline $\begin{array}{l}\text { Income from } \\
\text { management } \\
\text { and risk I }\end{array}$ & $\begin{array}{l}\text { Income from an agricultural holding after covering full economic costs } \\
\text { without subsidies not related to production (total revenues minus full } \\
\text { economic costs). }\end{array}$ \\
\hline $\begin{array}{l}\text { Income from } \\
\text { management } \\
\text { and risk II }\end{array}$ & $\begin{array}{l}\text { Income from management I increased by the amount of subsidies not related } \\
\text { to production (attributed to the forage area used in milk production). }\end{array}$ \\
\hline Breakeven point I & $\begin{array}{l}\text { Revenues from the sale of milk (milk price) equal to the total costs incurred } \\
\text { only for its production (milk price equal to total costs of raising dairy cattle } \\
\text { reduced by revenues other than the sale of milk). }\end{array}$ \\
\hline Breakeven point II & $\begin{array}{l}\text { Revenues from the sale of milk (milk price) equal to the full economic costs } \\
\text { incurred only for milk production (milk price equal to full economic costs } \\
\text { of raising dairy cattle reduced by revenues other than the sale of milk). }\end{array}$ \\
\hline
\end{tabular}

Source: own study based on the methodology of the EDF.

\section{Costs and profitability of milk production on farms in 2016}

Two groups of farms were covered by the analysis of the costs and profitability of milk production: the EDF and 30 Polish farms participating in the FADN. A tercile division was used within groups which means dividing entities into three categories of equal number. Full economic costs of producing $100 \mathrm{~kg}$ of milk $\left(\mathrm{ECM}^{2}\right)$ were adopted as the criterion for the division. The division made it possible to present differences in production and economic parameters on farms with higher and lower efficiency. Farms included in the lower (first) tercile (T1) accounted for $1 / 3$ of the number of farms and were characterised by the lowest full costs of milk production. The middle (second) tercile (T2) determined full economic costs of $2 / 3$ of farms. Whereas the upper (third) tercile (T3) determined the highest level of full costs incurred in other farms.

\footnotetext{
${ }^{2} \mathrm{ECM}$ - Energy Corrected Milk (fat content is $4.3 \%$ and protein content $3.5 \%$ ). The conversion of raw milk produced on farms into a comparable product in terms of content of basic ingredients was related to comparisons between farms.
} 
The basic characteristics of farms in the EDF and the Polish group are presented in Table 2. In the EDF group, the upper and lower terciles had 121 entities each, while the values for middle tercile were calculated on the basis of 120 farms. The Polish group was represented by 30 farms, and consisted of equipotent terciles (10 farms each). These farms belong to a very important group of entities from the point of view of milk production in Poland, which due to the economic size of farms can be considered as medium small, medium large and large. They constitute about $36 \%$ of entities maintaining cows in Poland, while these farms have about $74 \%$ of the cow population in Poland (GUS, 2017).

Significant differences in the production potential and the organisation of milk production can be observed in the studied groups. The size of the herd of cows in the Polish group was much smaller than in the EDF (about 8 times). Farms with the lowest total costs (T1) had two times more cows in a herd than farms in the upper terciles. The average milk yield of cows in the group of Polish farms was about $30 \%$ lower than in the EDF group, but the distance between the lower terciles of both groups was smaller than in the case of upper terciles. Culling of cows in the herd on the EDF farms was at a similar level in all terciles of farms and amounted to around $28 \%$. In the case of Polish farms, the exchange of cows in the herd was less frequent (culling at the level of 14\%) and there were large difference in its level in the terciles of farms.

The management of land resources on the Polish farms was different than in the case of the EDF farms both in terms of the ownership structure, the structure of the forage area, and the intensity of its use. The share of leased land on the EDF farms was significantly higher than on the Polish farms, which can be explained with the difference in the size of production units. Research indicates that the role of lease increases with UAA of a holding (Majchrzak, 2013). A feature distinguishing the Polish group of farms from the EDF was the structure of the forage area. Production of feed was mainly carried out on arable land (54\%) and temporary pastures (26\%). On EDF farms, the forage area was mostly grassland (around 60\%). The intensity of use of forage area measured by cow stocking was the lowest in the upper terciles of farms (1.4 stock unit/ha in the EDF and 1.1 stock unit/ha in PL). On the Polish farms, the stocking was at a similar level in all terciles, while the EDF farms of the lower and middle terciles were characterised by a much higher intensity of land use (1.7 head/ha).

The average capital involvement (without land) for milk production in both Polish and European EDF farms was similar (nearly PLN 32 thousand/cow). In the main part, inputs were related to the capital lock-up in machinery and buildings (over 60\%). However, it is worth noting that on the Polish farms the capital invested in machinery dominated (on average 36\%), while in the EDF group, the capital involved was mainly related to buildings and their equipment (46\%). Productivity of PLN 1 thousand of capital involved in milk production in the Polish group was about $30 \%$ lower than on average on the EDF farms, and comparing the results of farms from the first terciles of both groups, the difference was as high as $42 \%$ to the disadvantage of the Polish group. 
Table 2

Basic production and economic parameters of the analysed groups of farms from Poland and the EDF

\begin{tabular}{|c|c|c|c|c|c|c|c|c|c|}
\hline \multirow{2}{*}{ Detailed list } & \multirow{2}{*}{$\begin{array}{c}\text { Unit } \\
\text { of measure }\end{array}$} & \multicolumn{4}{|c|}{ EDF } & \multicolumn{4}{|c|}{ PL } \\
\hline & & $\varnothing \mathrm{EDF}$ & $\mathrm{T} 1$ & $\mathrm{~T} 2$ & $\mathrm{~T} 3$ & $\varnothing \mathrm{PL}$ & $\mathrm{T} 1$ & $\mathrm{~T} 2$ & $\mathrm{~T} 3$ \\
\hline The number of farms & Pieces & 362 & 121 & 120 & 121 & 30 & 10 & 10 & 10 \\
\hline Herd size & stock unit/farm & 235 & 313 & 236 & 156 & 30 & 39 & 32 & 18 \\
\hline Milk yield & $\mathrm{kg}$ of $\mathrm{ECM} / \mathrm{cow}$ & 8,777 & 8,911 & 9,184 & 8,241 & 6,778 & 7,912 & 6,875 & 5,548 \\
\hline Culling of cows in a herd & $\%$ & 28 & 28 & 29 & 27 & 14 & 8 & 12 & 22 \\
\hline Forage area, including: & ha & 153 & 160 & 170 & 130 & 27 & 35 & 28 & 17 \\
\hline Arable land & $\%$ & 39 & 40 & 42 & 35 & 54 & 55 & 55 & 51 \\
\hline Permanent pastures & $\%$ & 35 & 39 & 32 & 35 & 20 & 20 & 18 & 22 \\
\hline Temporary pastures & $\%$ & 25 & 20 & 26 & 30 & 26 & 25 & 27 & 27 \\
\hline Leased area & $\%$ of forage area & 52 & 55 & 56 & 47 & 17 & 16 & 23 & 12 \\
\hline Rent of arable land & $\begin{array}{c}\text { PLN/ha } \\
\text { of arable land }\end{array}$ & 1,728 & 1,487 & 1,777 & 1,921 & 759 & 740 & 795 & 741 \\
\hline Stocking of cows & stock unit/ha & 1.6 & 1.7 & 1.7 & 1.4 & 1.2 & 1.2 & 1.2 & 1.1 \\
\hline Land productivity & t of ECM/ha & 14.1 & 14.8 & 15.8 & 11.9 & 7.7 & 9.1 & 8.2 & 5.9 \\
\hline $\begin{array}{l}\text { Capital involvement } \\
\text { (without land), including: }\end{array}$ & $\begin{array}{c}\text { PLN } \\
\text { thousand/cow }\end{array}$ & 31.7 & 23.1 & 29.3 & 42.7 & 31.7 & 32.3 & 25.0 & 37.9 \\
\hline Value of buildings & $\%$ & 46 & 41 & 44 & 50 & 32 & 26 & 29 & 39 \\
\hline Value of machinery & $\%$ & 17 & 18 & 17 & 17 & 36 & 40 & 35 & 33 \\
\hline Capital productivity & $\begin{array}{l}\text { kg of ECM/ } \\
\text { PLN } 1000\end{array}$ & 6,888 & 8,598 & 7,087 & 4,983 & 4,852 & 5,036 & 5,858 & 3,663 \\
\hline Labour input & $\mathrm{h} / \mathrm{cow}$ & 58 & 52 & 47 & 75 & 175 & 130 & 148 & 247 \\
\hline Labour productivity & $\mathrm{kg}$ of ECM/h & 211 & 229 & 241 & 165 & 52 & 76 & 53 & 29 \\
\hline
\end{tabular}

Source: as for Figure 2.

Inputs of the labour factor in the Polish group of farms were three times higher than the average on the EDF farms. Research shows that farms adopt the structure of inputs, replacing more expensive factors with cheaper ones (Kusz and Misiak, 2017; Sheng, Davidson, Fuglie and Zhang, 2016).

The size of labour input on the Polish farms may result from low labour prices compared to the majority of countries taking part in the EDF cost analyses, with higher capital prices. Another reason for such high labour inputs on the analysed Polish farms was low production scale.

Management of resources remains closely related to farm production costs. In 2016 the milk prices on the market were lowfor the producers. In July 2016, the average price of milk was only $3 \%$ higher than in the corresponding period of 2009 , which was characterised by record low prices (European Comission, 2018a). 
Table 3 includes the economic results achieved in groups of the Polish farms and the EDF farms in 2016. Revenues from the sale of milk accounted for about $80 \%$ of the total revenues in raising of dairy cattle. Milk prices in the Polish group of farms were on average 20\% lower compared to the average EDF groups. On the EDF farms, the lowest prices were obtained by farms from the lower tercile (PLN $120.8 / 100 \mathrm{~kg}$ of ECM) and the highest from the upper tercile (PLN 162.5/100 kg of ECM). In the EDF, revenues from the sale of cattle accounted for around $13 \%$ of total revenues. A higher level of culling of cows in the herd on the Polish farms from the upper tercile resulted in a higher share of revenues from the sale of cattle (22\%).

On the majority of farms, direct costs accounted for over $50 \%$ of total costs in raising of dairy cattle. On average, on the EDF farms they amounted to PLN 76/100 $\mathrm{kg}$ of ECM, while in the Polish group they were PLN 17 (22\%) lower. On the Polish farms from the third tercile, direct costs were by PLN 22/100 kg of ECM higher compared to other farms.

Lower general economic costs on the Polish farms resulted mainly from lower costs of services (agricultural equipment and consultancy) as well as maintenance of machinery and equipment. The average depreciation cost on the EDF farms was PLN 21.6/100 kg of ECM and on the Polish farms it was higher by about PLN 4. Both categories of costs: general economic costs and depreciation were clearly increasing on farms from the second and third terciles of both groups.

The costs of using external factors on the Polish farms were lower compared to the EDF group. This was due to the low share of leases in the forage area and the use of only family labour in the production process.

Farms from lower terciles had lower total costs compared to farms from upper terciles. In the EDF group, this difference was PLN 60/100 kg of ECM and on the Polish farms PLN 50/100 kg of ECM. Total costs on the Polish farms were lower by about PLN 45/100 kg of milk compared to the EDF group. Income from the agricultural holding on the Polish farms from the lower and middle tercile was definitely higher than on the European farms from the analogous terciles (PLN 28.2 in the lower tercile and PLN 17.7 in the middle tercile).

The valuation of the costs of using own land, capital and labour resources made it possible to compare economic results regardless of the ownership structure of production factors. Due to the fact that milk production on the Polish farms was based mainly on own resources, alternative costs were at a definitely higher level than on the European farms (2.5 times). A particularly high level was achieved by alternative costs of family labour the outlay of which was three times higher. As a result, in 2016 income from management had negative values. The addition of subsidies not related to production in the account slightly improved the results, but only the EDF farms from the lower tercile achieved income from management (PLN 5.6/100 kg of milk). 
Table 3

Economic results in raising of dairy cattle in 2016 (PLN/100 kg of ECM)

\begin{tabular}{|c|c|c|c|c|c|c|c|c|}
\hline \multirow{2}{*}{ Detailed list } & \multicolumn{4}{|c|}{ EDF } & \multicolumn{4}{|c|}{ PL } \\
\hline & $ø \mathrm{EDF}$ & $\mathrm{T} 1$ & $\mathrm{~T} 2$ & $\mathrm{~T} 3$ & $ø \mathrm{PL}$ & $\mathrm{T} 1$ & $\mathrm{~T} 2$ & $\mathrm{~T} 3$ \\
\hline $\begin{array}{l}\text { Total revenues, including } \\
\text { from the sale of: }\end{array}$ & 170.3 & 150.0 & 159.9 & 201.0 & 136.4 & 138.1 & 129.3 & 141.7 \\
\hline milk & 138.6 & 120.8 & 132.3 & 162.5 & 110.2 & 112.7 & 111.1 & 106.9 \\
\hline cattle & 21.4 & 19.8 & 19.2 & 25.2 & 21.3 & 17.2 & 15.5 & 31.3 \\
\hline Direct costs, including: & 76.0 & 67.5 & 76.5 & 84.1 & 59.3 & 51.9 & 51.9 & 73.9 \\
\hline purchased feed & 44.5 & 40.4 & 47.0 & 46.2 & 22.7 & 23.8 & 20.8 & 23.3 \\
\hline production of own feed & 11.2 & 9.6 & 10.8 & 13.4 & 20.5 & 15.5 & 16.4 & 29.8 \\
\hline $\begin{array}{l}\text { other direct costs } \\
\text { (incl. purchase of animals) }\end{array}$ & 20.3 & 17.5 & 18.8 & 24.5 & 16.1 & 12.6 & 14.7 & 20.9 \\
\hline General economic costs & 33.2 & 24.5 & 31.4 & 43.6 & 20.0 & 13.1 & 20.9 & 26.0 \\
\hline Depreciation & 21.6 & 14.0 & 20.7 & 30.1 & 25.5 & 18.7 & 23.7 & 34.0 \\
\hline Cost of external factors & 21.9 & 19.3 & 20.0 & 26.4 & 2.2 & 1.5 & 3.8 & 1.4 \\
\hline Total costs & 152.7 & 125.3 & 148.6 & 184.2 & 106.9 & 85.2 & 100.3 & 135.3 \\
\hline Alternative costs, including: & 45.3 & 29.7 & 35.9 & 70.3 & 113.8 & 69.4 & 84.1 & 188.0 \\
\hline own land & 6.5 & 4.6 & 5.8 & 9.2 & 9.4 & 6.9 & 7.7 & 13.7 \\
\hline capital involved & 11.9 & 8.6 & 10.5 & 16.5 & 22.7 & 17.5 & 15.7 & 34.8 \\
\hline own labour & 26.9 & 16.5 & 19.6 & 44.5 & 81.7 & 45.0 & 60.8 & 139.5 \\
\hline Income from family farm & 17.7 & 24.7 & 11.3 & 16.8 & 29.5 & 52.9 & 29.0 & 6.4 \\
\hline $\begin{array}{l}\text { Income from management } \\
\text { and risk I }\end{array}$ & -27.7 & -5.0 & -24.6 & -53.5 & -84.4 & -16.5 & -55.1 & -181.6 \\
\hline $\begin{array}{l}\text { Income from management } \\
\text { and risk II }\end{array}$ & -14.0 & 5.6 & -13.2 & -34.4 & -62.7 & -1.3 & -38.4 & -148.3 \\
\hline
\end{tabular}

Source: as for Figure 2.

Total costs of producing $100 \mathrm{~kg}$ of milk were higher by about $30 \%$ on the EDF farms compared to Polish farms. Their average level on the Polish farms was PLN 80 per $100 \mathrm{~kg}$ of ECM, and on farms from the upper tercile did not exceed PLN 100, i.e. it was almost as high as on farms from the lower tercile of the EDF. Due to the inclusion of alternative costs in the calculation, the income from the sale of milk was lower than the full costs of its production in all groups of farms. 


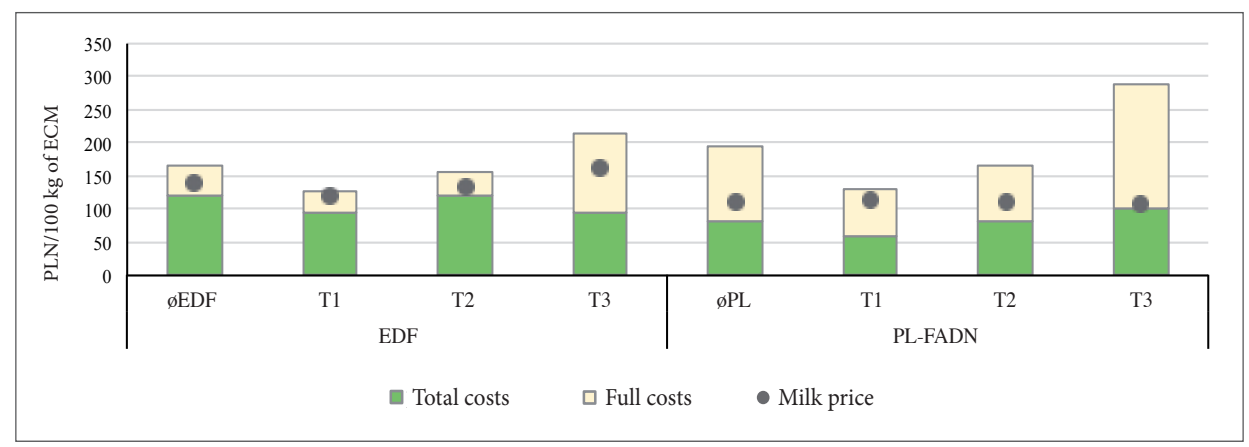

Fig. 3. Profitability of milk production in Polish and EDF farms in 2016.

Source: as for Figure 2.

\section{Production and economic results of farms in selected countries participating in the EDF}

The comparisons were made between groups of farms from countries which were represented by a minimum of 10 farms in the EDF. The number of farms representing the analysed countries accounted for $75 \%$ of the total number of farms participating in the EDF in 2016.

The analysed European farms were characterised by large herds of cows (Table 4). Only in three national groups, the average herd was smaller than 100 cows, while in Poland it was the smallest ( 30 head on average). Farms from Sweden and Denmark were characterised by very numerous herds of cows and achieved the highest milk yield (10.8 and $10.6 \mathrm{t}$ of ECM), with a very high rate of culling of cows in the herd.

Stocking of cows in national groups was characterised by a large span of values, from 0.8 on the Swedish and Polish farms, to 2.6 stock units/ha on the Spanish farms. The structure of forage area on the EDF farms was dominated by grassland (permanent and temporary). Only on the Spanish, Polish and Danish farms arable land accounted for the majority of the area intended for the production of feed. The highest share of leased area intended for the production of feed was noted on the French farms $(86 \%)$. The price of rent of agricultural land in this country was the lowest among the analysed national groups. The level of rent of agricultural land reflects, e.g. the value of agricultural land available on the market ${ }^{3}$. The highest rents for arable land were paid on the Dutch farms, and at the same time the share of leased area in the forage area of farms was among the lowest. A different situation was noted on the Belgian farms, where rent prices were not much lower, and the popularity of lease was significantly higher than in the neighbouring Netherlands. One of the fac-

\footnotetext{
${ }^{3}$ Based on the ranking of average national prices of agricultural land of the Institute of Agricultural and Food Economics, in 2016 in selected European countries with prices of rent in countries belonging to the EDF, a positive relationship between variables can be noted (European Commision, 2018b; Rynek ziemi, 2017).
} 
tors shaping the rent prices on the market is also land productivity (Swinnen, Ciaian and Kancs, 2008). High land productivity reflects high price of rent and stocking of cows primarily in Belgium, Denmark and the Netherlands.

Table 4

Selected production and organisational parameters of national groups of farms and the EDF in 2016

\begin{tabular}{|c|c|c|c|c|c|c|c|c|c|c|c|}
\hline Detailed list & & $\mathrm{BE}$ & $\mathrm{DE}$ & DK & ES & FR & IE & NL & PL & SE & UK \\
\hline $\begin{array}{l}\text { The number } \\
\text { of farms }\end{array}$ & units & 20 & 27 & 18 & 15 & 45 & 12 & 42 & 30 & 31 & 30 \\
\hline Herd size & $\begin{array}{l}\text { stock unit/ } \\
\text { farm }\end{array}$ & 75 & 371 & 392 & 104 & 220 & 92 & 104 & 30 & 450 & 248 \\
\hline Milk yield & $\begin{array}{l}\text { tof } \mathrm{ECM} / \\
\text { cow }\end{array}$ & 9.2 & 9.4 & 10.8 & 10.1 & 8.3 & 6.2 & 8.8 & 6.8 & 10.6 & 7.6 \\
\hline $\begin{array}{l}\text { Culling of cows } \\
\text { in a herd }\end{array}$ & $\%$ & 30 & 27 & 31 & 25 & 31 & 16 & 27 & 14 & 38 & 25 \\
\hline Arable land & $\begin{array}{c}\% \text { of forage } \\
\text { area }\end{array}$ & 43 & 48 & 58 & 77 & 48 & 2 & 15 & 54 & 28 & 15 \\
\hline Permanent pastures & $\begin{array}{c}\% \text { of forage } \\
\text { area }\end{array}$ & 57 & 46 & 6 & 7 & 20 & 98 & 66 & 20 & 21 & 51 \\
\hline Temporary pastures & $\begin{array}{c}\% \text { of forage } \\
\text { area }\end{array}$ & 0 & 6 & 37 & 16 & 32 & 0 & 19 & 26 & 51 & 33 \\
\hline Stocking of cows & stock unit/ha & 2.1 & 1.5 & 1.5 & 2.6 & 1.1 & 2.0 & 2.1 & 1.2 & 0.8 & 1.8 \\
\hline Leased area & $\begin{array}{c}\% \text { of forage } \\
\text { area }\end{array}$ & 68.5 & 69.0 & 35.0 & 54.0 & 86.4 & 40.5 & 27.0 & 17.0 & 62.2 & 54.3 \\
\hline Rent of arable land & $\begin{array}{c}\text { PLN/ha } \\
\text { of arable } \\
\text { land }\end{array}$ & 2,894 & 1,790 & 2,541 & 1,244 & 727 & 2,491 & 3,126 & 759 & 905 & 2,089 \\
\hline Land productivity & $\mathrm{t}$ of $\mathrm{ECM} / \mathrm{ha}$ & 19.3 & 13.8 & 16.7 & 26.8 & 9.4 & 12.7 & 18.9 & 7.7 & 8.8 & 13.3 \\
\hline $\begin{array}{l}\text { Capital involvement } \\
\text { (without land), } \\
\text { including: }\end{array}$ & $\begin{array}{l}\text { PLN } \\
\text { thousand/ } \\
\text { cow }\end{array}$ & 22.7 & 22.1 & 27.5 & 22.4 & 31.1 & 12.3 & 42.2 & 31.7 & 37.1 & 13.2 \\
\hline Value of buildings & $\%$ & 39 & 47 & 50 & 40 & 38 & 43 & 68 & 32 & 43 & 27 \\
\hline Value of machinery & $\%$ & 20 & 19 & 18 & 19 & 16 & 16 & 8 & 36 & 14 & 20 \\
\hline Value of livestock & $\%$ & 29 & 22 & 20 & 39 & 22 & 41 & 13 & 20 & 18 & 39 \\
\hline Capital productivity & $\begin{array}{l}\text { t of ECM/ } \\
\text { PLN } 1000\end{array}$ & 8.62 & 10.54 & 7.74 & 9.27 & 5.76 & 10.45 & 4.58 & 4.85 & 5.99 & 10.59 \\
\hline Labour input & $\mathrm{h} /$ cow & 38 & 42 & 30 & 62 & 46 & 32 & 31 & 175 & 46 & 35 \\
\hline Labour productivity & $\underset{\mathrm{ECM} / \mathrm{h}}{\mathrm{kg} \text { of }}$ & 261 & 238 & 380 & 185 & 203 & 214 & 312 & 52 & 249 & 231 \\
\hline
\end{tabular}

Source: as for Figure 2. 
Capital involved in assets (without land) per one cow on the Polish farms was on the level comparable with the French farms. In the comparison of the structure of capital involved in the analysed countries, large deviations from the share of machinery and buildings in capital in the national groups were noticeable. The Dutch farms were characterised by the highest capital involvement (PLN 42.2 thousand/ cow) and the value of buildings dominated in it (68\%). Despite high milk yield of cows, this resulted in the lowest capital productivity (4.58 t of ECM per PLN thousand of capital involved in milk production). The lowest capital involvement was noted for the Irish and British farms (PLN 12.3 and 13.2 thousand per cow, respectively), and its structure was characterised by a high share of livestock value. At the same time, farms from these countries were characterised by the highest capital productivity - over $10 \mathrm{t}$ of ECM/PLN 1000. Polish farms were characterised by the highest share of the value of machinery in capital (36\%). This share was more than twice as high as the average share on the EDF farms. As a consequence, relatively high capital intensity with low milk production on the Polish farms led to low capital productivity, comparable to the Dutch farms.

The average labour input per cow on the EDF farms in 2016 was 58 hours. The highest labour input was noted for the Polish farms $(175 \mathrm{~h})$. In other national groups, the labour input was ranging from $30 \mathrm{~h}$ per dairy cow on Danish farms to $62 \mathrm{~h}$ on the Spanish farms. Labour productivity was the highest especially in countries with high pay rates.

Revenues in milk production in national groups of farms were diversified (Table 5). The range of revenues between domestic groups was PLN 37. This was mainly due to differences in milk prices and prices of live bovine animals. The Swedish, French and Dutch farms produced the highest revenues. The Polish farmers obtained lower prices for milk produced, compared to other major milk producers in Europe (European Comission, 2018a; Wójcik, 2010).

In 2016, milk prices in the Polish group of farms were $20 \%$ lower compared to Dutch producers. Relatively low prices of milk were also obtained by producers from Belgium and Ireland. The sale of cattle also had a large share in the development of total revenues, especially on Irish farms in which it accounted for $20 \%$ of the total value of production (on Polish and Swedish farms this share was at the level of 16\%).

Total costs were different, ranging from PLN 99/100 kg of ECM on the Irish farms to PLN 158/100 kg of ECM on the Swedish farms. They were relatively favourable on the Irish and Polish farms. This was mainly due to low direct costs related to low costs of feeding cows. The highest total costs were incurred by the French and Swedish farms. The French farms were characterised by high depreciation (similarly to the Polish farms), but also high costs of using external production factors (mainly land).

Agricultural income was the most favourable in the group of the Irish and Polish farms. The inclusion of alternative costs in the assessment of profitability of milk production (both with subsidies and without subsidies not related to production) indicates good condition of Irish farms and, at the same time, very bad condition of the Polish farms. 
Table 5

Selected economic results of the EDF and national groups of farms in 2016

(PLN/100 kg of ECM)

\begin{tabular}{|c|c|c|c|c|c|c|c|c|c|c|}
\hline Detailed list & $\mathrm{BE}$ & $\mathrm{DE}$ & DK & ES & FR & IE & NL & PL & SE & UK \\
\hline Total revenues, including: & 133 & 147 & 142 & 157 & 168 & 144 & 163 & 136 & 170 & 157 \\
\hline from the sale of milk & 115 & 119 & 126 & 134 & 133 & 113 & 137 & 110 & 127 & 134 \\
\hline from the sale of cattle & 14.8 & 17.7 & 15.5 & 13.6 & 23.4 & 29.0 & 16.2 & 21.3 & 26.5 & 19.4 \\
\hline Direct costs, including: & 68.5 & 72.2 & 69.2 & 81.5 & 77.0 & 51.8 & 68.5 & 59.3 & 70.6 & 77.4 \\
\hline purchased feed & 39.2 & 42.3 & 46.7 & 54.0 & 39.7 & 20.4 & 42.9 & 22.7 & 41.7 & 40.2 \\
\hline production of own feed & 11.5 & 10.8 & 8.5 & 8.6 & 13.4 & 14.0 & 8.5 & 20.5 & 11.7 & 9.9 \\
\hline $\begin{array}{l}\text { other direct cost } \\
\text { (incl. purchase } \\
\text { of animals) }\end{array}$ & 17.7 & 19.1 & 14.0 & 19.0 & 23.9 & 17.4 & 17.1 & 16.1 & 17.2 & 27.2 \\
\hline General economic costs & 30.0 & 48.2 & 53.4 & 43.5 & 38.5 & 27.4 & 48.7 & 20.0 & 59.7 & 45.3 \\
\hline Depreciation & 23.0 & 15.1 & 14.2 & 12.7 & 31.0 & 9.6 & 21.3 & 25.5 & 22.1 & 11.3 \\
\hline Cost of external factors & 6.4 & 8.9 & 6.4 & 3.3 & 9.7 & 9.9 & 5.9 & 2.2 & 5.1 & 8.9 \\
\hline Total costs & 128 & 144 & 143 & 141 & 156 & 99 & 144 & 107 & 158 & 143 \\
\hline $\begin{array}{l}\text { Alternative costs, } \\
\text { including: }\end{array}$ & 44.3 & 30.3 & 24.6 & 28.3 & 44.8 & 45.3 & 55.1 & 114 & 31.8 & 27.4 \\
\hline own land & 3.4 & 4.5 & 10.5 & 2.9 & 1.2 & 11.2 & 13.3 & 9.4 & 3.8 & 7.0 \\
\hline capital involved & 7.6 & 7.2 & 8.5 & 5.5 & 10.7 & 6.9 & 15.1 & 22.7 & 10.2 & 8.8 \\
\hline own labour & 33.3 & 18.6 & 5.6 & 19.9 & 32.9 & 27.1 & 26.7 & 81.7 & 17.8 & 11.6 \\
\hline Income from family farm & 5.4 & 2.6 & -1.2 & 16.0 & 11.8 & 45.4 & 18.6 & 29.5 & 12.7 & 13.8 \\
\hline $\begin{array}{l}\text { Income from management } \\
\text { and risk I }\end{array}$ & -38.9 & -27.7 & -25.9 & -12.3 & -33.0 & 0.1 & -36.4 & -84.4 & -19.1 & -13.6 \\
\hline $\begin{array}{l}\text { Income from management } \\
\text { and risk II }\end{array}$ & -27.5 & -18.2 & -14.3 & -3.5 & -18.5 & 10.3 & -25.8 & -62.7 & -7.7 & -6.1 \\
\hline
\end{tabular}

Source: as for Figure 2.

Total costs of milk production on farms were characterised by high diversification (Figure 4). Their level was ranging from PLN 68 on the Irish farms to PLN 128 on the Danish group, however, in the majority of national groups, the cost of producing $100 \mathrm{~kg}$ of ECM did not exceed PLN 120. On average, alternative costs of producing $100 \mathrm{~kg}$ of milk in the analysed countries (except for Poland) amounted to approximately PLN 37. On the Polish farms, due to very large involvement of own resources (mainly labour) in milk production, alternative costs were almost three times higher than in other national groups. Only on the Irish farms the price of milk covered full costs of its production. On the other farms, production was unprofitable. Losses from milk production were ranging from PLN 12 on the Spanish farms to PLN 84 on the Polish farms for every $100 \mathrm{~kg}$ of ECM. 


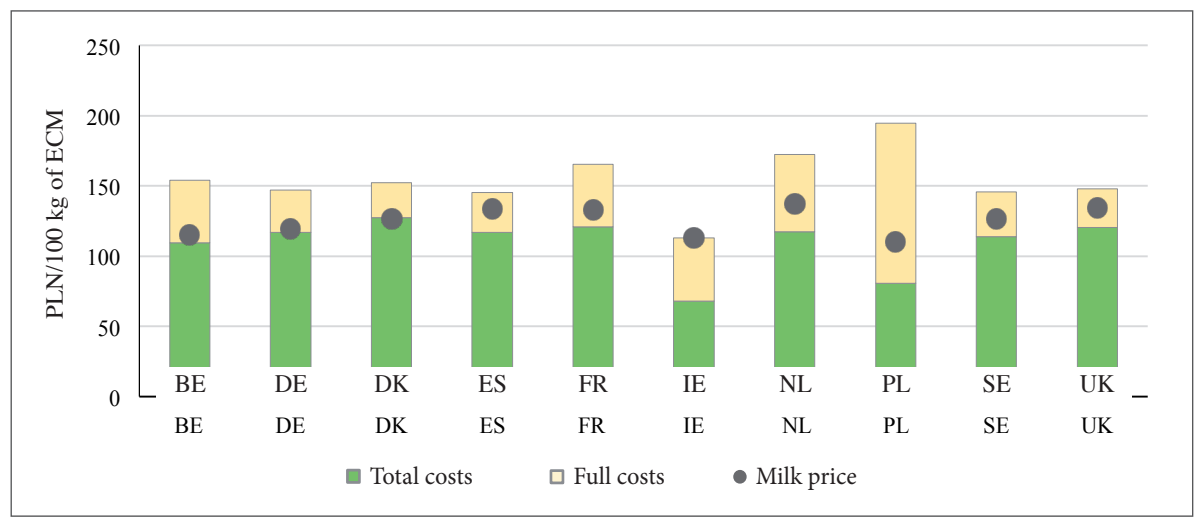

Fig. 4. Profitability of milk production in the national groups of EDF farms in 2016. Source: as for Figure 2.

\section{Conclusion}

1. Research has shown that it is possible to use the data collected by the FADN in network research conducted by the EDF. This requires either data from the FADN system to be supplemented with data collected using the structured interview or the FADN questionnaire to be supplemented with missing data.

2. A characteristic feature of farms incurring the lowest total costs was high production scale, associated with larger herds of cows (twice) and higher milk yield compared to farms incurring the highest costs.

3. On farms with low production costs, the area of leased UAA accounted for more than half of the forage area, and $59 \%$ of the produced feed came from grassland. In the Spanish, Danish and Polish group of farms, the production of feed was mainly on arable land, and on Danish and Polish farms, additionally, mainly on own land.

4. Farms incurring the lowest costs in raising of dairy cattle were characterised by low capital involvement (without land) per cow. It was dominated by the value of buildings. The Polish group of farms stood out in comparison with other groups with the highest share of machinery value in capital and one of the lowest capital productivity, alongside Dutch farms.

5. The analysis of costs on farms indicates that Irish and Polish farms had the lowest total costs. The average level of these costs in the Polish group was lower than the costs incurred on the EDF farms with the lowest full costs.

6. The valuation of own resources of farms used allowed comparing the results achieved regardless of the origin of production factors. Income from management and risk was achieved by farms with the lowest full costs of production and only taking into account subsidies for raising of dairy cattle in the calculation. Among the national groups, income from management was achieved 
only by the Irish farms, while the group of the Polish farms was characterised by the highest loss.

7. Total costs of producing $100 \mathrm{~kg}$ of milk on the Polish farms were lower than the costs of the EDF farms from the lower tercile. After taking into account alternative costs, milk production was profitable only in the group of the Irish farms. 


\section{References}

Bocian, M., Osuch, D., Smolik, A. (2018). Parametry techniczno-ekonomiczne wedtug grup gospodarstw rolnych uczestniczacych w Polskim FADN w 2016 roku. Warszawa: IERiGŻ-PIB.

Czyżewski, A., Guth, M. (2016). Zróżnicowanie produkcji mleka w makroregionach Unii Europejskiej z wyróżnieniem Polski. Warszawa: Wydawnictwo Naukowe PWN.

European Comission (2018a). EU Milk Market Observatory. Retrieved from: http://ec.europa. $\mathrm{eu} /$ agriculture/milk-market-observatory/latest-statistics/productions-stocks_en.htm.

European Commision (2018b). Land prices vary considerably between and within member states, (48). Retrieved from: ec.europa.eu/eurostat/documents/2995521/8756523/5-21032018-AP-EN.pdf/b1d0ffd3-f75b-40cc-b53f-f22f68d541df.

EDF (2015). EDF Report 2014. Frankfurt: European Dairy Farmers (EDF e.V.).

Gołaś, Z. (2017). Uwarunkowania rentowności produkcji mleka w gospodarstwach mlecznych krajów Unii Europejskiej. Zagadnienia Ekonomiki Rolnej, No. 3(352), pp. 19-40. DOI: $10.30858 /$ zer/83030.

Goraj, L., Mańko, S. (2004). Model szacowania pełnych kosztów działalności gospodarstw rolnych. Zagadnienia Ekonomiki Rolnej, No. 3(328), pp. 28-58.

GUS (2012). Charakterystyka gospodarstw rolnych. Powszechny Spis Rolny 2010. Warszawa: GUS.

GUS (2017). Charakterystyka gospodarstw rolnych w $2016 r$. Warszawa: GUS.

Hemme, T. (ed.). (2018). Dairy Report 2018. Kiel: IFCN.

Kusz, D., Misiak, T. (2017). Wpływ technicznego uzbrojenia pracy i postępu technicznego na wydajność pracy w rolnictwie. Roczniki Naukowe SERiA, vol. 19, No. 2, pp. 145-150. DOI: $10.5604 / 01.3001 .0010 .1177$.

Majchrzak, A. (2013). Rola dzierżawy gruntów rolnych w kształtowaniu struktury agrarnej Polski na tle państw członkowskich Unii Europejskiej. Problemy Drobnych Gospodarstw Rolnych, No. 2, pp. 63-82.

Rynek ziemi rolniczej. Stan i perspektywy (2017). Analizy Rynkowe, No. 20. Warszawa: IERiGŻ-PIB, ARR, MRiRW.

Sheng, Y., Davidson, A., Fuglie, K., Zhang, D. (2016). Input Substitution, Productivity Performance and Farm Size. Australian Journal of Agricultural and Resource Economics, 60(3), pp. 327-347. DOI: 10.1111/1467-8489.12136.

Skarżyńska, A. (2011). Koszty ekonomiczne produkcji mleka - metodyczne ujęcie rachunku oraz wyniki badań w 2009 roku. Zagadnienia Ekonomiki Rolnej, No. 3(320), pp. 143-161.

Skarżyńska, A. (2017). Wyniki gospodarstw mlecznych w Polsce w porównaniu do największych producentów mleka w Unii Europejskiej. Zagadnienia Ekonomiki Rolnej, No. 4(353), pp. 24-49. DOI: $10.30858 /$ zer/84963.

Swinnen, J., Ciaian, P., Kancs, A. (2008). Study on the functioning of land markets in the EU member states under the influence of measures applied under the Common Agricultural Policy. EERI Research Paper Series.

Wójcik, A. (2010). Dochodowość produkcji mleka w gospodarstwach w Europie. Roczniki Nauk Rolniczych, No. 97(1), pp. 122-130.

Ziętara, W., Adamski, M. (2018). Konkurencyjność polskich gospodarstw mlecznych na tle gospodarstw z wybranych Krajów Unii Europejskiej. Zagadnienia Ekonomiki Rolnej, No. 1(354), pp. 56-79. DOI: 10.30858/zer/89615. 


\title{
WYNIKI PRODUKCYJNE I EKONOMICZNE GOSPODARSTW MLECZNYCH NALEŻĄCYCH DO EUROPEJSKIEGO STOWARZYSZENIA PRODUCENTÓW MLEKA W 2016 ROKU
}

\begin{abstract}
Abstrakt
Celem oracowania byto sprawdzenie możliwości uzyskiwania danych z systemu FADN do ankiety EDF oraz porównanie wyników ekonomicznych osiaganych przez gospodarstwa mleczne z wybranych krajów UE w 2016 roku z zastosowaniem metodyki stosowanej przez EDF. Celem dodatkowym było określenie progu rentowności produkcji mleka na poziomie kosztów ogólnych oraz petnych. Do analizy wykorzystano dane średnie z gospodarstw EDF i grupy polskich gospodarstw. Gospodarstwa podzielono na tercyle ze względu na wysokość ponoszonych petnych kosztów produkcji $w$ chowie bydła mlecznego. Analizie poddano również średnie wyniki krajowe w ramach EDF w 2016 roku. Miarami oceny wyników byt poziom dochodu z gospodarstwa rolniczego oraz dochodu z tytułu zarządzania i ryzyka w chowie bydła mlecznego. Ocenie poddano również dwa progi rentowności wytworzenia $100 \mathrm{~kg}$ mleka na poziomie przychodów ze sprzedaży mleka pokrywajacych koszty ogólne oraz petne. Najniższe petne koszty produkcji ponosity gospodarstwa charakteryzujące się duża skala produkcji, liczba krów w stadzie oraz wydajnościa mleczną. Gospodarstwa te charakteryzowały się większym udziałem użytków zielonych niż gruntów ornych w powierzchni paszowej. Polskie i irlandzkie gospodarstwa charakteryzowały się najniższymi kosztami ogółem w chowie bydta mlecznego spośród analizowanych krajów. Na podstawie wyników obejmujących kalkulację kosztów wykorzystania własnych czynników w produkcji mleka należy stwierdzić, że polskie gospodarstwa osiagaty najniższy dochód z tytułu zarządzania i ryzyka. Poza gospodarstwami irlandzkimi produkcja mleka $w$ analizowanych krajach w 2016 roku była nierentowna.
\end{abstract}

Słowa kluczowe: rentowność, gospodarstwo mleczne, koszty produkcji mleka, dochód z gospodarstwa rolniczego.

Accepted for print: 15.03.2019.

Unless stated otherwise all the materials on the website are available under the Creative Commons Attribution 4.0 International license.

Some rights reserved to the Institute of Agricultural and Food Economics - National Research Institute.

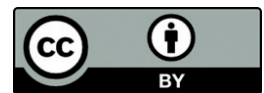

